\title{
An Economic Analysis on Turmeric Cultivation in Coimbatore District of Tamilnadu
}

\section{OPEN ACCESS}

Manuscript ID:

ECO-2021-09023747

Volume: 9

Issue: 2

Month: March

Year: 2021

P-ISSN: 2319-961X

E-ISSN: 2582-0192

Received: 04.01.2021

Accepted: 15.02.2021

Published: 01.03.2021

Citation:

Govindasamy, R., et al.

"An Economic Analysis on Turmeric Cultivation in Coimbatore District of Tamilnadu." Shanlax International Journal of Economcis, vol. 9, no. 2, 2021, pp. 59-65.

DOI:

https://doi.org/10.34293/ economics.v9i2.3747

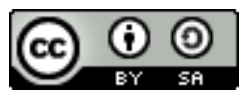

This work is licensed under a Creative Commons Attribution-ShareAlike 4.0 International License

\author{
R. Govindasamy \\ Assistant Professor, Department of Economics \\ Bharathiar University, Coimbatore, Tamil Nadu, India \\ https://orcid.org/0000-0002-3448-3966
}

\section{Dhanya Sai Das}

Ph. D. Research Scholar, Department of Economics

Bharathiar University, Coimbatore, Tamil Nadu, India

\author{
R. Tamilarasi \\ M. Phil Research Scholar, Department of Economics \\ Bharathiar University, Coimbatore, Tamil Nadu, India
}

\begin{abstract}
India is agrarian society where sole dependence has been on agriculture since time immemorial trading of agricultural produce began in exchange of money. Agriculture is the primary source of livelihood for about 58 percent of India's population. Gross Value Added (GVA) by agriculture forestry and fishing was estimated at Rs.19.48lakh Crore (Us\$276.37 Billion) in 7y 20(PE). Growth in GVA in agriculture and allied sectors stood at 4 percent in $7 Y$ 20. In 2020-21 Government of India is targeting total food grain production of 298 MT. Indian turmeric is the best in the world due to the presence of Cur cumin content. This study was conducted to assess the cost and profitability of cultivation of turmeric in the Coimbatore district. The data required for this study were collected from primary as well as secondary sources. Tools such as index number, mean, range, standard deviation and coefficient of variance are used for the present study. Both the Total Variable Cost and Total Fixed Cost were high for large farmers in the Coimbatore district, i.e., 40.17 percent and 13.44 percent respectively. It is concluded that turmeric cultivation is profitable with a Total Cost of production for an acre of Rs. 108794 and gross income from turmeric cultivation were Rs. 214821. The Net Income was Rs. 106027 per acre. The Cost-Benefit Ratio was greater than one. It indicates that the production of turmeric was highly remunerative and profitable for the growers. Keywords: Turmeric, Total variable cost, Total Fixed Cost, Cost Benefit Ratio, Cost and Profitability.
\end{abstract}

\section{Introduction}

India is agrarian society where sole dependence has been on agriculture since time immemorial trading of agricultural produce began in exchange of money. And from trading to the marketing of agriculture produce began although mostly it is a way of traditional selling. The market as a term is breaded than traditional trading. And agriculture marketing as a concept is still evolving in Indian society. In the olden days, agriculture produce was fundamentally bartered by nature where farmers exchange goods for goods and also agent services generally the scenario changed with the change time and agriculture produce for exchange of money. 
Agriculture is the primary source of livelihood for about 58 percent of India's population. Gross Value Added (GVA) by agriculture forestry and fishing was estimated at Rs.19.48 lakh Crore (US $\$ 276.37$ Billion) in the financial year 2020 (PE). Growth in GVA in agriculture and allied sectors stood at 4 percent in Financial year 20. In 2020-21 Government of India is targeting total food grain production of 298 MT.

India's GDP shrank by 23.9 percent in the June quarter due to covid-19 pandemic and the lockdown that followed. Agriculture sector emerged as the only savior giving hope for future. Agriculture is the only sector that has registered positive growth, i.e., 3.4 percent GDP growth and others were shown negative trend.

India is called the "Spices Bowl of the World" to produce a variety of spices with superior quality. Turmeric, a botanical name is called 'Curcuma longa', is essentially a crock of the tropics with conservation extended from India to Indo-China, East Indies, production of China and sir lank. It is the root of a plant of the ginger family and continues to be extensively used are such versatile spice throughout India the middle east and far eastern vegetarian and non-vegetarian food preparation. It is an annual crop the convention period required is one year. Growing spices for various purposes has been famous since ancient times. There are records about various spices and their properties in the Vedas as early as $6000 \mathrm{BC}$. India is well known for the trade since the exploration of sea routes because of its variety of spices and superior quality, which attracted foreigners to India. This is the key reason because of which India was invaded by European countries and was imperialized. To such an extent, India is famous for the spices.

Indian turmeric is the best in the world due to the presence of Curcumin content. Turmeric is also an important incident in cosmetics as well as in the pharmaceutical industry. Crop calendar the harvesting of a plant is done when the leaves of this plant start turning yellowish after7-10 month of plantation turmeric requires a warm and humid climate. It is harvested from January and in the by March. Arrivals start during February to April period. Turmeric is recognized as a Kharif crop in
India. The plantation starts in June and continues till August. The arrival of new crop starts coming in January month in Andhra Pradesh and packing in March due to strong supplies from TamilNadu and Maharashtra. Alleppey finger Kerala Erodes Salem, TamilNadu and Rajanpur Maharashtra. Among all these erode and raja pure varieties of the most popular in the international market as day contain the rich Cur cumin contents of around 3.5 to 4 percent.

Turmeric is grown as a kharif crop in India due to high Cur cumin content. India's turmeric major producing states are Andhra Pradesh, Tamil Nadu, Orissa, West Bengal and Karnataka and it contributes about 36 percent of total production. Tamil Nadu and Orissa place themselves are the second and third position sharing 26 percent and 14 percent, respectively India is also the largest consumer of turmeric in the world; India's domestic consumption accounts for nearly 90 percent of total production.

\section{Review of Literature}

Dhanalakshmi et al. (2018) in their study the production and cost and returns of turmeric cultivation were done, it was revealed that from the research that majority of the farmers were not adopting recommended application of micronutrients. The cost and return structure in turmeric cultivation for one hectare were shown in the total cost. The expenditure incurred of cultivation of turmeric was Rs 43,000 for control it was Rs 40,000. This indicates that the farmers are not adopting recommended practices on various inputs levels. The benefit-cost ratio (BCR) was 3.2, for control was realized by the sample farmer was 54.2 , concern with untreated it was $45.8 \mathrm{q} / \mathrm{ha}$. Farmers faced and realized, and the study revealed that the major problem faced by the growers in production are nonarability of time, lack of technical knowledge, lack of knowledge on the importance if micro-nutrient, inadequate market information and low productivity.

Chinnadurai. M et. al., (2018), this paper attempts to estimate the cost and economic returns of turmeric cultivation among various size categories (marginal, small, semi medium, medium and large), of farmers in Erode district of Tamil Nadu, which is one of the major turmeric growing region in India. The study results showed that of all the size categories, the 
economic returns realized by large farmers were comparatively higher..Besides ensuring reasonable price to the farmers, the study suggested value addition, like boiling, drying and grading of rhizomes to achieve maximum returns in turmeric cultivation.

\section{Objectives of the Study}

Following are the major objectives of the study;

- To examine the trend in area, production and productivity of turmeric in India.

- To assess the cost and profitability in the cultivation of turmeric in the Coimbatore district.

\section{Methodology}

The data required for this study were collected from primary as well as secondary sources. All the data used for the analysis were not related to the reference period due to the non-availability of continuous data. The time-series data on area, production and productivity of turmeric and export and import performance of turmeric in India related to (2008-09 to 2017-18). Primary data for the study were collected from the selected farmers (Turmeric growers) in Coimbatore District, Tamil Nadu. The field investigation for directly approach the farmers was carried out from January 2020 to March 2020.

The blocks in the Coimbatore district there more than 13 blocks. Among the maximum area under turmeric blocks such as Karamadai and Thondamuthur were selected. These two blocks account for 40 percent area under turmeric in the district. The villages of selected two blocks were listed, and two villages were selected randomly from each block. Finally, four villages were selected study from each selected village randomly. A Sample of 94 respondents was selected proportionate random sampling method. The latter the respondents were classified into two categories, namely viz., small farmers (below 3 acres) and large farmers (above 3 acres).

\section{Tools of Analysis}

The following tools were employed to analyze the data with reference to objective chosen for the study.
- The compound growth rate of all India Area, production, Productivity, State wise area, production, productivity.

- Index number, mean, range, standard deviation and coefficient of variance are used.

\section{Result and Discussion}

\section{All India Data}

\section{Area}

The data related to area production productivity of turmeric in India from 2008-09 to 2017-18 is provided in table 1 . The Area under Turmeric had increase from 181100 hectares in the year 2008-09 to 222000 hectares in 2017-18. The area under Turmeric reached the maximum of 232670 thousand hectares during the year 2013-14, while it was minimum of 0.83 thousand hectares during 2008-09. The Area indices worked out for showed a fluctuating trend. The area indices worked out for Turmeric showed less than hundred 99 in the Year 2009-10 during the reference Period. The Area indices were maximum with during the year 2013-14. The estimated compound growth rate of Area under Turmeric was Positive which was estimated to be 1.55 per cent. The Co-efficient of Variance under Turmeric the Area is 10.02 per cent.

\section{Production}

The General trend of production indicated shows that it had increased from 821200 tonnes in the year 2008-09 to 1070600 tonnes in the year 201718 with some fluctuating is in the intervening years. The production of Turmeric reached Maximum of 1166800 tonnes during the year 2011-12. And it was low in the year 791000 tonnes during the year 2012-13. The indices of Production of Turmeric reached maximum during the year 2013-14 with 144 per cent. The compound growth rate of Turmeric production was positive of 2.00 per annum during the reference period. The Co-Efficient of variance production under Turmeric is 15.82 per cent. 
International Journal of Economics

Table 1: Area, Production and Productivity of Turmeric in India from 2008-09 to 2017-2018

\begin{tabular}{|c|c|c|c|c|c|c|}
\hline \multirow{2}{*}{ Years } & \multicolumn{2}{|c|}{ Area } & \multicolumn{2}{c|}{ Production } & \multicolumn{2}{c|}{ Productivity } \\
\cline { 2 - 7 } & Hectare & Indices & Tones & Indices & Kg/Ha & Indices \\
\hline $2008-09$ & 181100 & 100 & 821200 & 100 & 4535 & 100 \\
\hline $2009-10$ & 181000 & 99 & 792980 & 96 & 4383 & 96 \\
\hline $2010-11$ & 195100 & 107 & 993000 & 120 & 5092 & 112 \\
\hline $2011-12$ & 219000 & 100 & 1166800 & 142 & 5377 & 117 \\
\hline $2012-13$ & 219000 & 100 & 791000 & 96 & 5000 & 110 \\
\hline $2013-14$ & 232670 & 128 & 1189890 & 144 & 5114 & 99 \\
\hline $2014-15$ & 184000 & 79 & 830000 & 101 & 4511 & 99 \\
\hline $2015-16$ & 185900 & 102 & 943300 & 114 & 5074 & 125 \\
\hline $2016-17$ & 221780 & 122 & 1050100 & 127 & 4762 & 105 \\
\hline $2017-18$ & 222000 & 122 & 1070600 & 130 & 4834 & 107 \\
\hline CGR & 1.55844 & - & 2.00623 & - & 0.399087 & - \\
\hline RANGE & 51670 & - & 398890 & - & 866 & - \\
\hline MEAN & 204155 & - & 964887 & - & 4868.2 & - \\
\hline SD & 20472.44 & - & 152649.6 & - & 318.9545 & - \\
\hline CV & 10.02789 & - & 15.82047 & - & 6.551795 & - \\
\hline
\end{tabular}

Area - '000 Hectares, Production - '000 Metric Tonnes, Yield - Kg/Hectare

Source: Horticultural Statistics at a Glance 2015

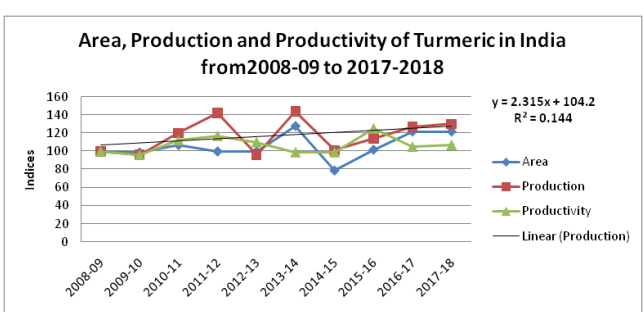

\section{Productivity}

The productivity trend of India shows that it has increased from $4535 \mathrm{~kg}$ per hectare in the year 2008-
09 to 4834 per hectares during 2017-18 with some fluctuating in the intervening years. The productivity of Turmeric reached the maximum of $5377 \mathrm{~kg}$ per hectare during 2011-12. And it was minimum of $4383 \mathrm{~kg}$ per hectare during the year 2009-10. The indices for productivity were Maximum during the year 2015-16 with 125 Per cent. The estimated compound growth rate of productivity of Turmeric was 0.399 per cent. The Co-efficient of Variance under Turmeric the productivity is of 6.55 per cent.

Table 2: Area and Yield Effect of Turmeric Production in India

\begin{tabular}{|c|c|c|c|c|c|c|c|c|}
\hline Country & Period & $\mathbf{A}_{\mathbf{0}}$ & $\mathbf{Y}_{\mathbf{0}}$ & $\Delta \mathbf{A}$ & $\Delta \mathbf{Y}$ & $\begin{array}{c}\text { Yield } \\
\text { Effect }\end{array}$ & $\begin{array}{c}\text { Area } \\
\text { Effect }\end{array}$ & $\begin{array}{c}\text { Interaction } \\
\text { Effect }\end{array}$ \\
\hline India & $2008-09$ to $2017-18$ & 181100 & 4535 & 40900 & 299 & 21.49 & 73.64 & 4.85 \\
\hline
\end{tabular}

Relative Contribution area and Productivity on Production

Table 2 shows that the effect of productivity, Area and interaction of Turmeric production in India during the period 2008-09 to 2017-18 are calculated. The total production of Turmeric increased during the reference period was about tonnes of which 73.64 percent, was due to increase in productivity, 21.43 percent was due to interaction between both Area and productivity. Area Effect is more than productivity Effect in the case of change in the total production of Turmeric. 


\begin{tabular}{|c|c|c|c|c|c|c|}
\hline Cost of Item & Small Farmers & Percent & Large Farmers & Percent & Overall & Percent \\
\hline \multicolumn{7}{|l|}{ A. Variable Cost } \\
\hline Land Preparation & 3300 & 3.08 & 3150 & 2.85 & 3225 & 2.96 \\
\hline Rhizomes Cost & 8000 & 7.48 & 8000 & 7.23 & 8000 & 7.35 \\
\hline Manure (FYM) & 9375 & 8.76 & 11374 & 10.28 & 10375 & 9.54 \\
\hline Fertilizer & 4264 & 3.99 & 4987 & 4.51 & 4626 & 4.25 \\
\hline Pesticides & 2734 & 2.56 & 2416 & 2.18 & 2575 & 2.37 \\
\hline Weed side Cost & 806 & 0.75 & 752 & 0.68 & 779 & 0.72 \\
\hline Irrigation Cost & 14500 & 13.55 & 14500 & 13.11 & 14500 & 13.33 \\
\hline Harvesting Cost & 11340 & 10.60 & 10500 & 9.49 & 10920 & 10.04 \\
\hline Boiling of Rhizomes & 2754 & 2.57 & 3251 & 2.94 & 3003 & 2.76 \\
\hline Drying & 3244 & 3.03 & 3532 & 3.19 & 3388 & 3.11 \\
\hline Polishing cost & 2172 & 2.03 & 2060 & 1.86 & 2116 & 1.94 \\
\hline Packing cost & 1215 & 1.14 & 1125 & 1.02 & 1170 & 1.08 \\
\hline Transport cost & 2164 & 2.02 & 1984 & 1.79 & 2074 & 1.91 \\
\hline Human Labour cost & 13522 & 12.64 & 15241 & 13.78 & 14382 & 13.22 \\
\hline Total Variable Cost (1 to 14$)$ & 79390 & 74.20 & 82872 & 74.93 & 81131 & 74.57 \\
\hline \multicolumn{7}{|l|}{ B. Fixed Cost } \\
\hline Rental Value of Land & 25000 & 23.37 & 25000 & 22.60 & 25000 & 22.98 \\
\hline Interest of fixed capital (10\%) & 2500 & 2.34 & 2500 & 2.26 & 2500 & 2.30 \\
\hline Land Tax & 100 & 0.09 & 225 & 0.20 & 163 & 0.15 \\
\hline Total Fixed Cost (1 to 3) & 27600 & 25.80 & 27725 & 25.07 & 27663 & 25.43 \\
\hline Total Cost $(\mathrm{A}+\mathrm{B})$ & 106990 & 100.00 & 110597 & 100.00 & 108794 & 100.00 \\
\hline Yield per acre & 25.42 & & 23.81 & & & \\
\hline Selling Price per Quintal & 8100 & & 8100 & & & \\
\hline
\end{tabular}

Source: Primary Data

\section{Total Cost}

The total cost of both small and large farmers was given in the table 3. It involves both Total Fixed Cost as well as Total Variable Cost. The Total Cost of large farmers (i.e., Rs.110597 per acre) is greater than the small farmers (i.e., Rs.106990 per acre) in the Coimbatore district. As compared to large farmers there is only small difference (Rs. 3607 per acre) in the overall cost of small farmers, because the small farmers have to incur more expenses on fertilizers and pesticides as their land holding is comparatively small that of large farmers.

\section{Total Fixed Cost}

From the table 3 , it is evident that the Total Fixed Cost involves the rental value of land, interest of fixed capital and the tax on land. The percentage of
Total Fixed Cost for small farmers (25.80 percent) is greater than that of large farmers (25.07 percent).

\section{Total Variable Cost}

Table 3 reveals Total Variable cost incurred by both large as well as small farmers \& it includes cost on land preparation, harvesting, irrigation, human labour, manure and so on. The overall Total Variable Cost of large farmers (Rs.82872 per acre) was higher than that of small farmers (Rs.79390 per acre).

Table 4: Cost and Returns of Turmeric Cultivation in Coimbatore District

\begin{tabular}{|l|c|c|c|}
\hline \multicolumn{1}{|c|}{ Particulars } & $\begin{array}{c}\text { Small } \\
\text { Farmers }\end{array}$ & $\begin{array}{c}\text { Large } \\
\text { Farmers }\end{array}$ & Overall \\
\hline Yield in Quintal & 25.42 & 23.81 & 24.62 \\
\hline Price & 8100 & 8100 & 8100 \\
\hline
\end{tabular}




\begin{tabular}{|l|c|c|c|}
\hline Value of Turmeric & 205902 & 192861 & 199382 \\
\hline Intercrop income & 17431 & 13447 & 15439 \\
\hline Gross Return & 223333 & 206308 & 214821 \\
\hline Total Cost & 106990 & 110597 & 108794 \\
\hline Net Income & 116343 & 95711 & 106027 \\
\hline
\end{tabular}

Source: Primary Data

Table 4 reveals the cost and returns of turmeric cultivation in Coimbatore district. It has been found that the total cost incurred by the large farmers as compared to small farmers was relatively high i.e., Rs.110597. In case of the gross return, the small farmers earn Rs. 223333 i.e., more than that of large farmers. The yield of small farmers (25.42) was high as compared to large farmers (23.81).

Table 5: Profitability of Turmeric Cultivation in Coimbatore District

\begin{tabular}{|l|c|c|c|c|}
\hline Particulars & $\begin{array}{c}\text { Small } \\
\text { Farmers }\end{array}$ & $\mathbf{\%}$ & $\begin{array}{c}\text { Large } \\
\text { Farmers }\end{array}$ & $\mathbf{\%}$ \\
\hline $\begin{array}{l}\text { Total Variable } \\
\text { Cost }\end{array}$ & 79390 & 35.55 & 82872 & 40.17 \\
\hline $\begin{array}{l}\text { Total Fixed } \\
\text { Cost }\end{array}$ & 27600 & 12.36 & 27725 & 13.44 \\
\hline $\begin{array}{l}\text { Cost of } \\
\text { Production }\end{array}$ & 106990 & 47.91 & 110597 & 53.61 \\
\hline Gross Return & 223333 & 100 & 206308 & 100 \\
\hline Net Return & 116343 & & 95711 & \\
\hline $\begin{array}{l}\text { Input Output } \\
\text { Ratio }\end{array}$ & 2.08 & & 1.86 & \\
\hline $\begin{array}{l}\text { Cost Benefit } \\
\text { Ratio }\end{array}$ & 1.08 & & 0.86 & \\
\hline
\end{tabular}

Source: Primary Data

From the table 5, it is clear that both the Total Variable Cost as well as Total Fixed Cost were high for large farmers in Coimbatore district i.e., 40.17 per cent and 13.44 per cent respectively. The gross return and net return the small farmers yields more i.e., Rs.223333 and Rs.116343 per acre respectively. It is very much clear from the table that the cost benefit Ratio was more for small farmers (1.08) as compared to large farmers (0.86).

\section{Conclusion}

It has been found that the Total Cost of large farmers (i.e., Rs.110597 per acre) is greater than the small farmers (i.e. Rs. 106990 per acre) in the
Coimbatore district. As compared to large farmers there is only small difference (Rs. 3607 per acre) in the overall cost of small farmers, because the small farmers have to incur more expenses on fertilizers and pesticides as their land holding is comparatively small that of large farmers.

In case of the gross return, the small farmers earn Rs. 223333 i.e., more than that of large farmers. The yield of small farmers (25.42) was high as compared to large farmers (23.81). The Total Variable Cost as well as Total Fixed Cost were high for large farmers in Coimbatore district i.e., 40.17 per cent and 13.44 per cent respectively. The gross return and net return the small farmers yields more i.e., Rs.223333 and Rs.116343 per acre respectively. It is very much clear from the table that the cost benefit Ratio was more for small farmers (1.08) as compared to large farmers (0.86).

It is concluded that turmeric cultivation is profitable with Total Cost of production for acre of Rs. 108794 and gross income from turmeric cultivation was Rs. 214821. The Net Income was Rs. 106027 per acre. The Cost-Benefit Ratio was greater than one it indicates that the production of turmeric was highly remunerative and profitable for the growers.

\section{Suggestions}

- The farmers may engage in intercropping (such as chilli, onion and tomato) in turmeric cultivation.

- Should ensure more subsidies to the farmers (such as fertilizer, pesticides, farm equipment and irrigation development).

- The government should give natural fertilizer for the turmeric growers.

- The government should give more knowledge to the farmers to get more productivity in a small land.

\section{References}

Begum, M.E.A., et al. "Economic Analysis of Turmeric Cultivation: Evidence from Khagrachari District." Bangladesh Journal of Agricultural Research, vol. 44, no. 1, 2019, pp. 43-58.

Chigadolli, Mutteppa, et al. "A Study on Extent of Adoption of Improved Cultivation Practices 
by Turmeric Growers in Belagavi District, Kanthe, Ravindra U., and Venkatesh Yashwant Karnataka, India." International Journal of Current Microbiology and Applied Science, vol. 8, no. 3, 2019, pp. 2411-2418.

Chinnadurai, M., et al. "Economics of Turmeric Cultivation in Erode District of Tamil Nadu." Agricultural Science Digest, vol. 38, no. 4, 2018, pp. 293-296.

Dhanalakshmi, K., et al. "Production and Economics of Turmeric Cultivation." International Journal of Current Microbiology and Applied Sciences, vol. 7, no. 11, 2018, pp. 3496-3502. Govindasamy, R. "Production and Export Performance of Turmeric in India." Shanlax International Journal of Economics, vol. 3, no. 1, 2014, pp. 47-59. Badave. "Marketing of Turmeric in the Sangli District, Maharashatra, India." International Journal of Economics and Management Sciences, vol. 5, no. 5, 2016.

Kiruthika, N. "The Economics of Production of Turmeric in India: A Case Study of Erode District of Tamil Nadu." Journal of Innovative Research and Solutions, vol. 1, no. 1, 2013, pp. 23-30.

Saeed, R., et al. "An Economic Assessment of Turmeric Production in Punjab-Pakistan." Pakistan Journal of Agriculture Agricultural Engineering and Veterinary Sciences, vol. 33, no. 1, 2017, pp. 85-99.

\section{Author Details \\ Dr. R. Govindasamy, Assistant Professor, Department of Economics, Bharathiar University, Coimbatore, Tamil Nadu, India, Email ID: govindh.phd@gmail.com}

Dhanya Sai Das, Ph. D. Research Scholar, Department of Economics, Bharathiar University, Coimbatore, Tamil Nadu, India

R. Tamilarasi, M.Phil. Research Scholar, Department of Economics, Bharathiar University, Coimbatore, Tamil Nadu, India 